\title{
Origin of Jordanian honeybees Apis mellifera (Hymenoptera: Apidae) using amplified mitochondrial DNA
}

\author{
Shahera ZAITOUN, Dhia S. HASSAWI* and Wesam SHAHROUR
}

Al-Balqa Applied University, Faculty of Agricultural Technology, Al-Salt 19117, Jordan; e-mail: dhassawi@yahoo.com

Key words. Apidae, apiculture, honeybee, geographic subspecies, mitochondrial lineages, mtDNA

\begin{abstract}
The honeybee (Apis mellifera L.) has a large number of geographic subspecies distributed across Europe, Africa and Asia, many of which have been described. This identification is important for bee breeding and preserving honeybee biodiversity. To investigate the origin of Jordanian honeybees, 32 samples collected from different locations in Jordan were analyzed using four different enzyme systems: Bg/II site in cytochrome oxidase b (Cytb), EcoRI site in large ribosomal (lsRNA) subunit, XbaI site in cytochrome c oxidase I (COI) subunit and HinCII site in cytochrome c oxidase I (COI) subunit. The first three enzymes were found to be polymorphic. The DNA banding pattern analyses revealed that Jordanian honeybees belong to the East Mediterranean and Middle Eastern mitochondrial lineages.
\end{abstract}

\section{INTRODUCTION}

Honeybee keeping in Jordan is an important aspect of the agricultural economy. The total number of honeybee colonies in Jordan is around 40 thousands, and the total amount of honey produced is 150 tons; this amount represent only $20 \%$ of the local consumption of honey (Agricultural statistical year report, 2005).

The bee race in Jordan is Apis mellifera syriaca (Syrian honeybee), which is a native of the Eastern Mediterranean region (Jordan, Palestine, Syria and Lebanon). It is characterized by bright yellow color, small size, aggressiveness and a tendency to construct several swarm cells (Ruttner, 1988). This honeybee subspecies is tolerant of the environmental conditions prevailing in the Jordan valley and mountain areas of Jordan (Zaitoun, 2000). However, in comparison with other honeybee subspecies, this bee is not easy to manage because it is aggressive and produce little honey. For these reasons, many Jordanian beekeepers have imported queens and bees of other subspecies, such as A. m. carnica from Germany and Egypt, A. $m$. ligustica from Italy and the United State of America, and A. m. anatoliaca from Turkey. In addition, Jordan is also adjacent to the borders of Africa, so African honeybee subspecies may be transported into the country either accidentally or by beekeepers. The imported subspecies are not correctly identified and mating between the different subspecies could occur, producing new hybrids.

Honeybees (Apis mellifera) are geographically diverse; with as many as 25 subspecies (Ruttner, 1988; Sheppard et al., 1997). Biodiversity of the honeybee was first assessed using morphometrics. Ruttner et al. (1978) proposed the existence of three distinct branches, a South and Central African, a North African and West European, and a North Mediterranean branch. This classification was further refined by the addition of a fourth evolutionary branch that includes the Near and Middle Eastern subspecies (Ruttner, 1988). Many other scientists have suggested classifications based on morphometric characters (Cornuet et al., 1988; Cornuet \& Fresnaye, 1989; Ruttner, 1992; Crewe et al., 1994; Sheppard et al., 1997; Engel, 1999). Morphological characters are not well suited for phylogeographical studies because they can be sensitive to environmental selection pressures, need a lot of time and experience, and some times are unsuitable for identifying some hybrids (Franck et al., 2000).

Current trends in the application of DNA marker techniques in a diversity of insect ecological studies show that mitochondrial DNA (mtDNA), microsatellites, random amplified polymorphic DNA (RAPD), expressed sequence tags (EST) and amplified fragment length polymorphism (AFLP) markers have contributed significantly to our understanding of the genetic basis of insect diversity (Behura, 2006).

Data on mtDNA have confirmed the presence of three lineages in Africa, Western Europe and South-Eastern Europe (Smith \& Brown, 1988; Crozier et al., 1991; Garnery et al., 1992, 1993; Moritz et al., 1994; Sheppard et al., 1996). The existence of a fourth mitochondrial lineage in the Middle East has also been confirmed (Arias \& Sheppard, 1996; Franck et al., 2000b; Antina et al., 2000; Palmer et al., 2000; Meixner et al., 2000). Several other studies have shown the power of mtDNA in revealing genetic variation and providing insights into the biogeography of honeybees (Hall, 1986; Smith \& Brown, 1988, 1990; Hall \& Muralidharan, 1989; Smith et al., 1989; Cornuet \& Garnery, 1991; Hall \& Smith, 1991; Smith, 1991a, b).

Identification and classification of honeybees is essential for the breeding and improvement of honeybees in Jordan. The aim of this research was to analyze the

\footnotetext{
* Corresponding author:
} 
TABLE 1. Summary of the pairs of primers, location of amplified fragment, restriction enzymes and detected bands.

\begin{tabular}{|c|c|c|c|c|}
\hline \multirow{2}{*}{ Primer pair } & \multirow{2}{*}{ Location of amplified fragment } & \multirow{2}{*}{$\begin{array}{l}\text { Restriction } \\
\text { enzyme }\end{array}$} & \multicolumn{2}{|c|}{ Detected bands } \\
\hline & & & E. M.* & M. E.** \\
\hline $\begin{array}{l}5^{\prime} \text { TATGTACTACCATGAGGACAAATATC 3' } \\
3^{\prime} \text { TAAGGATTATTTAATCCTCCACATTA 5' }\end{array}$ & cytochrome oxidase b (Cytb) & $B g / \mathrm{II}$ & + & + \\
\hline $\begin{array}{l}\text { 5' TTTTGTACCTTTTGTATCAGGGTTG 3‘ } \\
3^{\prime} \text { CCCTGCTATTCTGGGATATC 5’ }\end{array}$ & large ribosomal subunit (lsRNA) & EcoRI & + & - \\
\hline $\begin{array}{l}5^{\prime} \text { TCTATACCACGACGTTATTC } 3^{\prime} \\
3^{\prime} \text { CCAGTAGTTACTATAACTAG 5' }\end{array}$ & $\begin{array}{l}3^{\prime} \text { end cytochrome oxidase I to 5' end } \\
\text { cytochrome oxidase II (COI-COII) }\end{array}$ & $X b a I$ & + & - \\
\hline $\begin{array}{l}5^{\prime} \text { 'TTAAGATCCCCAGGATCATG 3', } \\
3^{\prime} \text { GTTATCCACGTCATAAACGT 5' }\end{array}$ & 5 ' end cytochrome oxidase I (COI) & HinCII & - & - \\
\hline
\end{tabular}

*E. M. - Eastern Mediterranean; **M. E. - Middle Eastern. Note: The EcoRI site in the large ribosomal subunit is potentially polymorphic both in the Eastern Mediterranean and Middle Eastern lineages.

mtDNA (restriction sites and length polymorphism) of different honeybee populations in Jordan in order to determine their origin and evolution.

\section{MATERIAL AND METHODS}

\section{Sample collection}

Thirty two honeybee colonies were sampled from 14 locations in different geographical regions and bio-climates of Jordan (North: Irbid, Jarash, Ash-Shuna Ash-Shamaliyya, Dayr Alla, and Wadi Alyabes; North East: Az-Zarqa; Middle: Amman, As-Salt, Wadi Shuayb, Al-Kryma, and Alsuru; South: Ash-Shuna Ajanubia; West: Al-Ghor, Humrat-Alsahen). Bees were immediately killed by immersion in absolute ethanol (Scharlau, Barcelona, Spain) and then stored at $-70^{\circ} \mathrm{C}$ until used for DNA extraction. Two Mediterranean queens of Apis mellifera carnica, introduced from Germany, were used as a control.

\section{DNA extraction}

DNA was extracted from single thorax of frozen bees following the method of Smith et al. (1997). Each thorax was crushed in $500 \mu 1$ of sterile STE buffer $0.1 \mathrm{M} \mathrm{NaCl}$ (Scharlau), 0.05 M Tris pH 7.5 (Sigma, Tau Arzneimittel GmbH, Dusseldorf, Germany), and 0.001 M EDTA pH 7.8 (Scharlau), $25 \mu$ of $20 \%$ sodium lauryl sulphate (Scharlau) and $25 \mu \mathrm{l}$ of $10 \mathrm{mg} / \mathrm{ml}$ proteinase-K (Promega, Madison, Wisconsin, USA). The mixture was then incubated for $2 \mathrm{~h}$ at $56^{\circ} \mathrm{C}$ in a water bath. After incubation, the mixture was extracted with $(25: 24: 1)$ phenol: chloroform: isoamyl alcohol (Sigma) followed by $(24: 1)$ chloroform: isoamyl alcohol. DNA was precipitated with $1: 10$ volume of $3 \mathrm{M}$ sodium acetate (Scharlau) and two volumes of cold absolute ethanol. DNA was pelleted by centrifuging for 15 min at $12000 \mathrm{rpm}$. The pellet was rinsed once in $70 \%$ ethanol, air dried and resuspended in $100 \mu 1$ of TE buffer (10 mM Tris, 1 mM EDTA pH 7.8).

\section{Primers and PCR amplifications}

Four regions of the mitochondrial genome were amplified with four primer pairs (Table 1) by means of polymerase chain reaction (PCR) using the following thermal profile: $94^{\circ} \mathrm{C}$ for 5 min, 35 cycles of $94^{\circ} \mathrm{C}$ for $20 \mathrm{~s}, 40^{\circ} \mathrm{C}$ for $1 \mathrm{~min}, 72^{\circ} \mathrm{C}$ for $1 \mathrm{~min}$ and finished with $72^{\circ} \mathrm{C}$ for $5 \mathrm{~min}$. Each PCR reaction $(25 \mu \mathrm{l})$

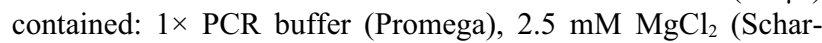
lau), $0.1 \mu \mathrm{M}$ of each primer (Promega), $0.5 \mu \mathrm{l}(5 \mathrm{U} / \mu \mathrm{l})$ of $\mathrm{Taq}$ polymerase (Promega), $10 \mathrm{mM}$ dNTPs (Promega) and $5 \mu \mathrm{l}$ DNA.

\section{Digestion with restriction enzymes}

Each PCR amplification product was digested with the appropriate restriction enzyme (Table 1) using the following: $5 \mu 1$ of
PCR product, $0.2 \mu \mathrm{l}$ of BSA (Promega), $2 \mu 1$ of enzyme buffer (Promega) and $1 \mu \mathrm{l}$ of restriction enzyme (Promega); the final volume was adjusted to $20 \mu \mathrm{l}$ by adding sterile distilled water. The mixture was incubated at $37^{\circ} \mathrm{C}$ for $3 \mathrm{~h}$.

\section{Gel electrophoresis}

The resulting restriction fragments were separated by electrophoresis on a $2 \%$ agarose gel with $1 \times$ TBE buffer $(0.1 \mathrm{M}$ Trisborate, $0.2 \mathrm{mM}$ EDTA, $0.1 \mathrm{M}$ boric acid $\mathrm{pH} 8.3$ ). The gel was then stained with ethidium bromide and examined under ultraviolet illumination. Restriction sites were scored as present (PCR amplification product cut, resulting in two bands) or absent (PCR amplification product not cut, resulting in one band).

\section{RESULTS AND DISCUSSION}

The genetic variation in 32 honeybee colonies collected from different locations in Jordan was analyzed using four discriminating restriction enzymes. The $\mathrm{Bg} / \mathrm{II}$ site in cytochrome oxidase b (Cytb), EcoRI site in large ribosomal (lsRNA) subunit, and $X b$ aI site in cytochrome c oxidase I (COI) subunit were present, while the HinCII site in (COI) subunit was absent in the samples that revealed restriction sites for the East Mediterranean lineage. The $B g / I I$ site was present, while the other three sites were absent in the samples that revealed restriction sites for the Middle Eastern lineage (Table 1).

Figs 1, 2 and 3 show the polymorphic fragment patterns of Jordanian honeybee DNA digested with the restriction enzymes $B g / \mathrm{II}, E c o$ RI and $X b \mathrm{aI}$, respectively. In Fig. 1,

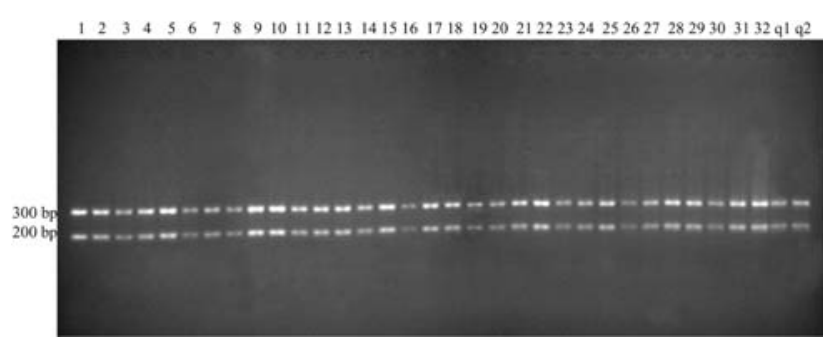

Fig. 1. PCR products of Cytb digested by $B g / I I$ enzyme. Samples in lanes $(1-3,5-9)$ collected from the Northern part of Jordan; in lanes $(4,21,32)$ from the Western part of Jordan; in lanes $(10,30,31)$ from the North Eastern part of Jordan; in lanes $(11-20,22,23,24,28,29)$ from the Middle part of Jordan; in lanes $(25,26,27)$ from the Southern part of Jordan; in lanes (q1 and q2) the control queens. 


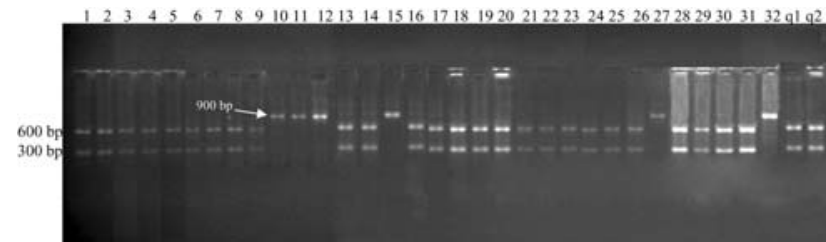

Fig. 2. PCR products of lsRNA digested by EcoRI enzyme. Samples in lanes $(1-3,5-9)$ collected from the Northern part of Jordan; in lanes $(4,21,32)$ from the Western part of Jordan; in lanes $(10,30,31)$ from the North Eastern part of Jordan; in lanes $(11-20,22,23,24,28,29)$ from the Middle part of Jordan; in lanes $(25,26,27)$ from the Southern part of Jordan; in lanes (q1 and q2) the control queens.

the cleaved $500 \mathrm{bp}$ amplified fragments yielded two bands ( $300 \mathrm{bp}$ and $200 \mathrm{bp}$ ) in all samples. In Fig. 2, the $900 \mathrm{bp}$ amplified fragments in six samples $(10,11,12$, 15, 27 and 32) were not cleaved, while the other 26 samples plus the two queens were cleaved yielding two bands (600 bp and $300 \mathrm{bp}$ ). In Fig. 3, the $1400 \mathrm{bp}$ amplified fragments in five samples $(4,11,12,15$ and 32$)$ and the $1000 \mathrm{bp}$ amplified fragments in two samples (10 and 25) were not cleaved, while the other 25 samples plus the two queens that have $900 \mathrm{bp}$ amplified fragments were cleaved yielding two bands (700 bp and $200 \mathrm{bp}$ ). In Fig. 4, which represents DNA digested with HinCII enzyme, none of the $1400 \mathrm{bp}$ amplified fragments were cleaved. The DNA patterns resulting from the use of four restriction enzymes correspond to the Middle Eastern type in five samples (10, 11, 12, 15 and 32) and the East Mediterranean type in most of the samples.

The different DNA patterns of samples 4, 25 and 27 in Figs 2 and 3 may be informative. Samples 4 and 25 were digested with EcoRI but undigested with $X b a \mathrm{I}$; these two samples might include mitotypes related to the Middle East lineages and could result from DNA insertion or deletion in their genome. Sample 27 was digested by $X b a \mathrm{I}$ but not with EcoRI; this sample might include the North Mediterranean mitotype II, according to the nomenclature of Smith et al. (1997). In order to clarify this, DNA sequencing of the three samples is required.

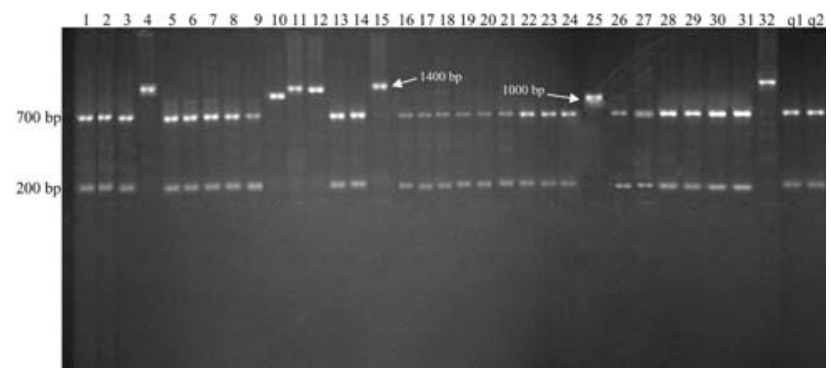

Fig. 3. PCR products of COI-COII digested by XbaI enzyme. Samples in lanes $(1-3,5-9)$ collected from the Northern part of Jordan; in lanes $(4,21,32)$ from the Western part of Jordan; in lanes $(10,30,31)$ from the North Eastern part of Jordan; in lanes $(11-20,22,23,24,28,29)$ from the Middle part of Jordan; in lanes $(25,26,27)$ from the Southern part of Jordan; in lanes (q1 and q2) the control queens.

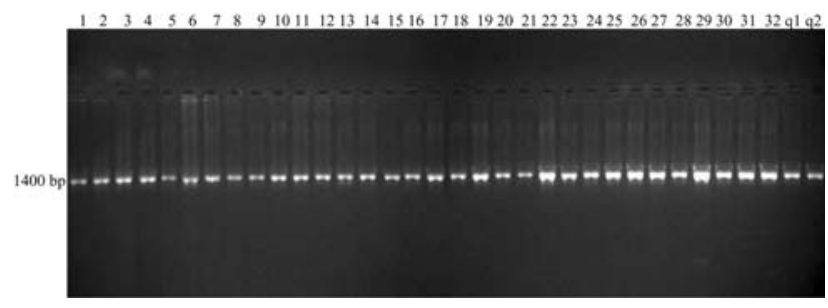

Fig. 4. PCR products of COI digested by HinCII enzyme. Samples in lanes $(1-3,5-9)$ collected from the Northern part of Jordan; in lanes $(4,21,32)$ from the Western part of Jordan; in lanes $(10,30,31)$ from the North Eastern part of Jordan; in lanes $(11-20,22,23,24,28,29)$ from the Middle part of Jordan; in lanes $(25,26,27)$ from the Southern part of Jordan; in lanes (q1 and q2) the control queens.

Also, a comparison of the resultant sequences of the mtDNA and genome sequences of the honeybee (Vlasak et al., 1987; Crozier et al., 1989; The Honey Bee Genome Sequencing Consortium, 2006.) might also prove useful. Palmer et al. (2000) also mention the existence of two types of the East Mediterranean lineage in Turkey.

The data provided by the mtDNA markers confirmed the existence of the Middle Eastern lineage in Jordan. The existence of this evolutionary lineage, which includes mellifera subspecies from the Middle East era accords with the results of previous studies by Frank et al. (2000b) and Palmer et al. (2000). This finding also accords with maternal transmission of mtDNA, which does not reflect the genetic contribution of the drones of the colonies.

Franck et al. (2001) mention that the presence of the Middle East mitochondrial lineage in Egypt and Somalia may result from successive honeybee invasions of Africa from the Middle East, as the Horn of Africa and the Rift Valley are the main channels for colonizing species from Asia.

This study proved that variation in the mitochondrial molecule can be used to discriminate among the evolutionary lineages of honeybee subspecies, and that the EcoRI site in the (lsRNA) subunit gene and the XbaI site in the (COI) subunit gene are found in bees of the East Mediterranean group (Smith, 1988; Smith \& Brown, 1988, 1990; Hall \& Muralidharan, 1989; Smith et al., 1989, 1991; Crozier et al., 1989; de la Rúa et al., 2001).

If queen replacement is maintained or increased over the next years in Jordan, the genetic pool of local populations may be severely disrupted. Therefore, a policy aimed at preserving local populations is required as humans can greatly modify the genetic architecture of honeybee populations.

ACKNOWLEDGMENTS. We thank Al-Balqa Applied University for supporting this research.

\section{REFERENCES}

Agricultural Statistical Year Report 2005: Ministry of Agriculture, Jordan, Amman.

Antia M.C., Walter S.S. \& Hachiro S. 2000: A scientific note on the identification of honeybee semen using a mitochondrial DNA marker. Apidologie 31: 595-596. 
Arias M.C. \& Sheppard W.S. 1996: Molecular phylogenetics of honeybee subspecies (Apis mellifera L.) inferred from mitochondrial DNA sequences. Mol. Phyl. Evol. 5: 557-566.

BeHURA S.K. 2006: Molecular marker systems in insects: current trends and future avenues. Mol. Ecol. 15: 3087-3113.

Cornuet J.M. \& Fresnaye J. 1989: Biometrical study of honeybee populations from Spain and Portugal. Apidologie 20: 93-101.

Cornuet J.M. \& Garnery L. 1991: Mitochondrial DNA variability in honeybees and its phylogeographic implications. Apidologie 22: 627-642.

Cornuet J.M., Daoudi A., Mohssine H. \& Fresnaye J. 1988 : Étude biométrique de populations d'abeilles Marocaines. Apidologie 19: 355-366.

Crewe R.M., Hepburn H.R. \& Moritz R.F.A. 1994: Morphometric analysis of 2 southern African races of honeybee. Apidologie 25: 61-70.

Crozier R.H., Crozier Y.C. \& Mackinlay A.G. 1989: The CO-I and CO-II region of honeybee mitochondrial DNA: evidence for variation in insect mitochondrial evolutionary rates. Mol. Biol. Evol. 6: 399-411.

Crozier Y.C., Koulianos S. \& Crozier R.H. 1991: An improved test for Africanized honeybee mitochondrial DNA. Experientia 47: 968-969.

De la Rúa P., Galián J. \& Serrano J. 2001: Molecular characterization and population structure of the honeybees from the Balearic Islands (Spain). Apidologie 32: 417-427.

ENGEL M.S. 1999: The taxonomy of recent and fossil honey bees (Hymenoptera: Apidae; Apis). J. Hym. Res. 82: 165-196.

Franck P., Garnery L., Solignac M. \& Cornuet J.M. 2000: Molecular confirmation of a fourth lineage in honeybees from the Near East. Apidologie 31: 167-180.

Franck P., Garnery L., Loiseau A., Oldroyd B.P., Hepburn H.R., Solignac M. \& Cornuet J.M. 2001: Genetic diversity of the honeybee in Africa: microsatellite and mitochondrial data. Heredity 86: 420-430.

Garnery L., Cornuet J.M. \& Solignac M. 1992: Evolutionary history of the honeybee Apis mellifera inferred from mitochondrial DNA analysis. Mol. Ecol. 1: 145-154.

Garnery L., Solignac M., Celebrano G. \& Cornuet J.M. 1993 A simple test using restricted PCR-amplified mitochondrial DNA to study the genetic structure of Apis mellifera L. Experientia 49: 1016-1021.

Hall H.G. 1986: DNA Differences found between Africanized and European honeybees. Proc. Natl. Acad. Sci. 83: 4874-4877.

Hall H.G. \& Muralidharan K. 1989: Evidence from mitochondrial DNA that African honeybees spread as continuous material lineages. Nature 339: 211-213.

Hall H.G. \& SмITH D.R. 1991: Distinguishing African and European honeybee matrilines using amplified mitochondrial DNA. Proc. Natl. Acad. Sci. 88: 4548-4552.

Meixner M.D., Arias M.C. \& Sheppard W.S. 2000: Mitochondrial DNA polymorphisms in honey bee subspecies from Kenya. Apidologie 31: 181-190.

Moritz R.F.A., Cornuet J.M., Kryger P., Garnery L. \& HepBURN H.R. 1994: Mitochondrial DNA variability in South
African honeybees (Apis mellifera L.). Apidologie 25: 169-178.

Palmer M.R., Smith D.R. \& KaftanoĐlu O. 2000: Turkish honeybees: genetic variation and evidence for a fourth lineage of Apis mellifera mtDNA. J. Heredity 91: 42-46.

RutTner F. 1988: Biogeography and Taxonomy of Honeybees. Springer, Berlin, $284 \mathrm{pp}$.

RUTTNER F. 1992: Naturgeschichte der Honigbienen. Ehrenwirth, München, $357 \mathrm{pp}$.

Ruttner F., Tassencourt L. \& Louveaux J. 1978: Biometricalstatistical analysis of the geographic variability of Apis mellifera L. Apidologie 9: 363-381.

Sheppard W.S., Rinderer T.E. Meixner M.D., Yoo H.R., Stelzer J.A., Schiff N.M., Kamel S.M. \& Krell R. 1996: Hinfl variation in mitochondrial DNA of Old World honeybee subspecies. J. Heredity 87: 35-40.

Sheppard W.S., Arias M.C., Grech A. \& Meixner M.D. 1997: Apis mellifera ruttneri, a new honey bee subspecies from Malta. Apidologie 28: 287-293.

SмITH D.R. 1988: Mitochondrial DNA polymorphism in five Old World subspecies of honey bees in New World hybrids. In Needham G.R., Page R.E.Jr., Delfinado-Baker M. \& Bowman C. (eds): Africanized Honey Bees and Bee Mites. Ellis Horwood, Chichester, UK, pp. 303-312.

SмIтн D.R. 1991a: African bees in the Americas: Insights from biogeography and genetics. Trends Ecol. Evol. 6: 17-21.

SмITH D.R. 1991b: Mitochondrial DNA and honey bee biogeography. In Smith D.R. (ed.): Diversity in the Genus Apis. West view Press and IBH Publ., Oxford. pp. 131-176.

SмITH D.R. \& BRown W.M. 1988: Mitochondrial DNA restriction site polymorphism in American and Africanized honey bees (Apis mellifera). Experientia 44: 257-260.

Sмiтh D.R. \& Brown W.M. 1990: Restriction endonuclease cleavage site and length polymorphisms in mitochondrial DNA of Apis mellifera and A. m. carnica (Hymenoptera: Apidae). Ann. Entomol. Soc. Am. 83: 81-87.

SMith D.R., Brown W.M. \& TAYlor O.R.JR. 1989: Neotropical Africanized bees have African mitochondrial DNA. Nature 339: 213-215.

Smith D.R., Palopoli M.F., Taylor B.R., Garnery L., Cornuet J.M., Solignac M. \& Brown W.M. 1991: Geographic overlap of two mitochondrial genomes in Spanish honeybees (Apis mellifera iberica). J. Heredity 82: 96-100.

Smith D.R., Slaymaker A., Palmer M. \& Kaftanolgu O. 1997: Turkish honeybees belong to the east Mediterranean mitochondrial lineage. Apidologie 28: 269-274.

The Honey Bee Genome Sequencing Consortium 2006: Insights into social insects from the genome of the honeybee Apis mellifera. Nature 443: 931-949.

Vlasak I., Burgschwaiger S. \& Kreil G. 1987: Nucleotide sequence of the large ribosomal RNA of honeybee mitochondria. Nucl. Acids Res. 15: 2388.

Zaitoun S.T. 2000: Population dynamics of the Syrian Honeybee, Apis mellifera syriaca, under semi-arid Mediterranean conditions. The Seventh IBRA Conference on Tropical Bees: Management and Diversity. 19-26 March 2000. Chiang Mai, Thailand, pp. 319-321.

Received April 11, 2007; revised and accepted August 14, 2007 